\title{
ЦИФРОВОЕ РАБСТВО ИЛИ ЭЛЕКТРОННЫЙ РАЙ?
}

\author{
Пивень П. В."
}

В статье рассматриваются сочиально-философские проблемы, связанные с формированием информационного общества в Российской Федерации. Оиениваются возможные риски, связанные с утратой личного пространства; с различными манипуляциями общественным мнением и сознанием политическими интриганами и представителями бизнеса; с использованием электронных технологий и ресурсов для совершения различных преступлений в области морали и права. Анализируются последствия возможного уничтожения традиционного уклада жизни населения страны в результате повсеместного внедрения новых информационных технологий. Оцениваются риски возможной патологической зависимости людей от Интернета и различных электронных гаджетов; рассматриваются вопросы, связанные с возможной подменой реального мира виртуальным как способом ухода от повседневных проблем. Анализируется возможность гармоничного сосуществования представителей информационного и традищионного обществ.

Ключевые слова: информационное общество, интернет-зависимость, информационный шок, манипуляции общественным сознанием, электронные технологии, дегуманизация.

The article examines social and philosophical problems associated with the formation of information society in the Russian Federation. The author assesses the possible risks associated with the loss of personal space, with various manipulation of public opinion and consciousness by political intriguers and business representatives; with the use of electronic technologies and resources to commit various crimes in the sphere of morality and law. The consequences of the possible destruction of the traditional way of life as a result of the widespread introduction of new information technologies are considered in this paper. The author also assesses risks of possible pathological dependence of people on the Internet and various electronic gadgets. He considers the issues associated with the possible substitution of the reality by virtual reality as a way of avoiding daily problems. The possibility of harmonious coexistence of representatives of the information and traditional societies is examined.

Keywords: information society, internet-addiction, information shock, manipulation of social consciousness, electronic technologies, dehumanization.

Еще в конце XIX и начале XX в. проблемы дегуманизации общества в связи с переходом к «машинной» цивилизации волновали умы философов. Произошел слом традиционных устоев общества, что вызвало культурный кризис. Выход из него искали поэты, художники, музыканты и - философы. Среди них можно назвать В. Дильтея, Ж.-П. Сартра, А. Камю, К. Ясперса, Э. Фромма и др. Данные

\footnotetext{
* Пивень Павел Владиславович - к. ф. н., доцент кафедры природопользования и геоэкологии ФГБОУ ВО «Алтайский государственный университет» (г. Барнаул). E-mail: piven@mc.asu.ru.
}

Век глобализации 4/2018 107-113

DOI: $10.30884 / v g l o b / 2018.04 .10$ 
философы пытались противостоять абсолютистскому технократизму, дегуманизирующему человечество. Становление и развитие сети Интернет, появление новых информационных технологий обостряет вышеуказанные проблемы и актуализирует вопросы, связанные с возможностью гармоничного сосуществования традиционного и информационного обществ, сохранения национальных культур, национальной самоидентичности.

Распоряжением Правительства РФ от 28 июля 2017 г. № 1632-р была утверждена программа «Цифровая экономика Российской Федерации» [Правительство...]. По сути, планируется коренное изменение жизненного уклада населения страны в целом. Если учесть тот факт, что федеральная целевая программа «Электронная Россия» (2002-2010) была по большей части провалена, не будет ли это очередной попыткой строительства воздушных замков? Ведь и принятая вслед за «Электронной Россией» государственная программа «Информационное общество» (распоряжение Правительства РФ № 1815-р от 20 октября 2010 г.) [Там же] также испытывает проблемы по реализации. Насколько готова Россия к переходу на «электронные рельсы», если учесть тот факт, что в 2016 г., по данным Счетной палаты РФ, около 31 \% медучреждений страны не имело водопровода, а в $35,5 \%$ случаев - канализации [Годовые...]? Состояние сферы здравоохранения РФ в целом может отражать общую ситуацию, сложившуюся с системами жизнеобеспечения социума. Слоган «Интернет в каждый дом!» перестанет звучать как издевка лишь тогда, когда граждане РФ смогут решить свои куда более насущные проблемы (это все равно что предлагать электрообогреватель замерзающим при отсутствии электричества).

Не станет ли экономика страны при переходе на цифровую модель виртуально-эфемерной, отражающей лишь «палочные», количественные, «дутые», а не реальные, качественные показатели? Приписки и желаемые для «красивой» отчетности корректировки статистических данных были, есть и будут. А электронные технологии открывают для подобных подтасовок очень широкие возможности. Например, коррупционерам-чиновникам для видеоотчетов (с помощью программы «Фотошоп» можно «ремонтировать» изображения дорог, «убирать» нелегальную рекламу с улиц, попросту стирая ее со снимков, и т. п.). Наконец, есть и такой фундаментальный вопрос: что произойдет с обществом, если сломать его традиционный жизненный уклад?

Информационные технологии становятся основополагающим фундаментом современного мирового сообщества. Можно говорить о том, что научнотехническая революция перешла на новый этап - планетарно-электронный. Избыток информации становится нормой жизни, при этом для привлечения к ней внимания используются все более и более яркие «манки», основанные на пробуждении животных начал, сексе и насилии. Не стоит забывать о том, что любая информация может быть использована как во благо, так и во зло (знание анатомии человека может помочь как исцелять, так и убивать). Обрушивающаяся на человека лавина информации может попросту вызвать информационный шок (о футурошоке упоминал еще в 70-е гг. XX в. Э. Тоффлер [2002]). Для примера: если человека оглушить подрывом светозвуковой гранаты, то он может на время или навсегда потерять способность слышать и видеть. Если человека «оглушить» информационным взрывом, то он может аналогично потерять способность к вос- 
приятию и анализу приходящих извне сведений, подобно моллюску, который, защищаясь от агрессии внешнего мира, прячется в своей раковине.

Информационный поток может стать определяющим в развитии как отдельно взятой личности, так и общества в целом. Информация может превратиться в средство, сметающее государственный строй. С учетом того, что массовое применение современного атомного оружия не оставит после себя победителей и побежденных, а будет лишь выжженная пустыня, над которой ветер развеет радиоактивный пепел былой жизни, открытые военные конфликты стали вестись лишь локально. В глобальном же масштабе для уничтожения политических и экономических соперников сверхдержавы стали вести полномасштабные информационные войны. Информационным атакам подвергается как внешняя, так и внутренняя деятельность государств. Стали создаваться школы по подготовке информационных диверсантов, хакеров, профессиональных организаторов-провокаторов «цветных революций». В настоящее время тот, кто в большей степени овладел информационными технологиями, становится хозяином положения и может навязывать свою волю другим. Так, государственная машина США пытается воплотить свои стратегические инициативы в том числе посредством применения информационных технологий (пси-кодировки общественного сознания, кибератаки на информационные сети, в том числе банковские, неугодных правящих режимов). Уже во второй половине XX в. наметились тенденции всевозрастающего электронного тоталитаризма. Так, Ж. Эллюль говорил об опасности превращения мира информатики в агента технической системы, ведущего к тотальному, всепроникающему контролю над людьми [Эллюль 1986]. Ну а когда государствокиборг окрепнет, его граждане ничего не смогут противопоставить этому монстру. Уже в настоящее время в такой «демократически развитой» стране, как США, по мере развития информационных технологий можно заметить все нарастающий тотальный контроль над населением со стороны «Большого Брата». Например, повсеместно установленные видеокамеры отслеживают каждый шаг, каждый вздох, любое поведение, которое покажется девиантным такому беспристрастному арбитру, как компьютер.

Технократизм привел и к пагубным изменениям человека как такового. Так, К. Ясперс отмечал, что уже в его время люди постепенно стали превращаться в некие придатки машин, утрачивая свою человечность (по сути - становиться биороботами) [Ясперс 1986: 144]. Если обратиться к такому научно-философскому направлению, как сциентизм, то проблемы, порожденные научно-техническим прогрессом, могут быть им же решены. Но может ли техническое, порождающее искусственное, добиться гармонии с естественным? По мнению Х. Сколимовски, миф всесилья и всевластья техники программирует западный способ мышления. Техника стала как физической, так и ментальной опорой жизни общества. Это приводит к тому, что проблемы, порожденные абсолютистски-техногенным путем развития, пытаются решить опять же при помощи техники [Сколимовски 1986: 246]. К сожалению, в настоящее время научно-технический прогресс превратился в одну из «священных коров», на которых зиждется могущество западной цивилизации. Любые попытки привлечь внимание ко все большей дегуманизации человечества вызывают бурю негодования у технократов. Так, Р. Коэн среди прочих проблем современного мира выделяет «фетишизм науки, идущий параллельно с фетишизмом потребления, вещизмом» [Коэн 1986: 217]. 
Электронная среда открывает большие возможности для осуществления различных преступлений как в области права, так и в области морали. Чего стоят «группы смерти» - клубы самоубийц в соцсетях. Средствами Всемирной электронной паутины, далеко не в благих целях, пользуются извращенцы-педофилы, маньяки, террористы, сектанты и в первую очередь мошенники-проходимцы различных специализаций: от брачных до банковских аферистов. Так, если ошейник домашнего питомца оснащен GPS-трекером, связанным с вашим сотовым телефоном (посредством GSM/GPRS-сети), то четвероногий друг без ведома хозяина может «подписаться» на платный контент. Да что там, даже неодушевленные предметы, подключенные к глобальной сети Интернет, на это «способны» (игрушки, электрические чайники, реле ворот, шлагбаумы, а уж если гражданин решился проживать в «умном доме», то практически любой выключатель и даже унитаз).

Поисковые запросы пользователей Интернета собираются и анализируются сетью, на каждого из них автоматически собирается досье. Можно выяснить, каких политических взглядов придерживается тот или иной человек, какие социальные проблемы его волнуют, какие продовольственные или непродовольственные товары он предпочитает, где (и с кем) любит проводить свободное время и т. п.

Этими данными пользуются не только ушлые маркетологи, автоматической рассылкой рекламы продвигая свой товар, но и другие ловцы человеческих душ. Любой сотовый телефон (или аналогичный гаджет) позволяет отследить перемещения своего владельца по интерактивной карте. По схожим радиометкам можно выявить круг его знакомых и друзей, места, время и продолжительность встреч. Есть шпионские программы, позволяющие прослушать разговоры, даже если телефон находится в режиме ожидания. Глазок камеры ноутбука позволяет и без желания владельца устроить из его личной жизни реалити-шоу, а вмонтированный в устройство микрофон - дать соответствующее звуковое сопровождение. «Умный» телевизор, подключенный к сети Интернет, - это не только «окно» во внешний мир, но и потенциальное «окно» для злоумышленников в мир обитателей квартиры. Хакеры могут взломать бортовую электронику транспортного средства, перехватить его управление и устроить аварию [UConnect...]. Ну а уж про конфиденциальность электронной переписки и говорить не приходится - она лишь условна.

Лично я (автор данной статьи) никогда не имел своего компьютера, не пользуюсь сотовым телефоном и тому подобными устройствами, отсутствую в соцсетях. Среди моих предков были былинные новгородцы и запорожцы - люди Воли. Ходить на электронном поводке не для меня. Отсутствие личных электронных гаджетов не помешало мне выполнить и защитить дипломную работу, как впоследствии и кандидатскую диссертацию. Свобода - величайший дар от Всевышнего. Можно оставаться вольным даже в кандалах, но если дух человека сломлен и подчинен тварным началам, то он становится рабом: денег, коварной алчной женщины, алкоголя или иного дурмана, затмевающего свет разума. Тяготы повседневной жизни приводят к тому, что люди стремятся достичь забвения и в виртуальном мире, подменяя им реальный. Слабый физически, безвольный и «затурканный» представитель «офисного планктона» в компьютерных играх может примерить на себя образ культового героя. Чем больше страшит его реальность, 
тем больше он будет погружаться в электронную трясину, предпочтя кажущийся уход от проблем суровой необходимости их решения.

Проблемы компьютерной и интернет-зависимости уже довольно широко были освещены отдельными статьями [Бурова 2000; Дрепа 2009; Севостьянова, Уривская 2016] и нашли свое отражение в монографиях [Больбот, Юрьева 2006]. Глобальная виртуальная среда способна подчинить и растворить в себе даже патриархальные сообщества, в которых соблюдение вековых традиций было возведено в ранг национальной идеи. Например, к таким государствам относится Япония. Информационное общество, все разрастаясь, проникая во все новые сферы общественной жизни, практически не оставляет места традиционному жизненному укладу, он все больше уходит в область туристической экзотики. Для людей начинают стираться границы реального мира и виртуального, они теряют связь с реальностью. Насколько эта проблема может быть остра для общества, свидетельствует тот факт, что в Японии хикикомори (самозатворники, не выходящие из дома, «приросшие» к своим компьютерам) составляют уже как минимум $10 \%$ трудоспособного населения [Suwa, Suzuki 2013]. Подобных людей становится все больше, в том числе и в других странах с развитой цифровой экономикой (например, в США и Южной Корее) [Тео 2013]. Эта зараза, подобно наркомании, разъедает народ, превращает его представителей в бездумных потребляющих тварей, подобно лабораторным животным, тыкающим кнопки для получения очередной дозы «кайфа», и грозит полным уничтожением наций. Неслучайно специалисты, занимающиеся лечением интернет-зависимости, употребляют в названиях своих работ довольно резкие выражения, например: «Укрощение цифровой обезьяны...» [Пан 2014]. Оскотинивание человека может происходить не только от наркотической, но и от других видов патологической зависимости.

Информационные технологии все чаще и во все больших объемах используются для контроля и различных манипуляций по работе с сознанием как отдельных личностей, так и общества в целом различными структурами - от политического истеблишмента до ТНК и сект. По Г. Бехману, Интернет представляет собой некую матрицу новой социально-технической парадигмы, преобразующей реальный мир в подобие виртуального, развивая сетевое общество, становясь базисом человеческой жизни [Бехман 2010]. Эта матрица тех же японцев довела уже до такого состояния, что они в качестве спутников жизни стали предпочитать роботов или аниме-виртуальные модели живым людям. Утрачиваются навыки социальной коммуникации, а это грозит распадом общества как единой социальной целостности.

М. Кастельс основополагающей структурой общества и его движущей силой, обеспечивающей динамику развития, считает коммуникационную власть. Именно она способна формировать и изменять сознание людей. Именно она способна задавать направления чувств и мыслей, программирует то, как люди будут решать возникающие проблемы. Это касается не только отдельно взятой личности, но и общества в целом [Кастельс 2016]. Конечно, всегда найдутся белые вороны, чье мнение отличается от общепринятого, коллективного. Но таких личностей всегда стремятся сломать, переделать под существующие шаблоны, и их контрмнение чаще всего тонет в общем информационном потоке.

Увеличение численности и, соответственно, потребностей растущего населения, приводящее к истощению природных ресурсов на территории его прожива- 
ния, вызывает ответную реакцию - экспансию (военную, политическую, экономическую, культурную) в другие страны, необходимый для этого рост военных расходов, постепенную милитаризацию общества, что, в свою очередь, приводит к усилению диктата правящего режима, тоталитаризму. Если народ отучают иметь свое мнение, заставляют поступать не по совести, а по приказу, то это постепенно ведет к духовной деградации. Дальнейшая же хищническая эксплуатация природных ресурсов, в том числе и на поддержание мощного военноадминистративного аппарата, приводит к их истощению и на вновь освоенных территориях. Эти два слагаемых - деградация среды обитания и духа народа ведут к внутреннему надлому государства, оно начинает «пожирать» само себя и может исчезнуть с мировой арены вследствие внутренних или внешних конфликтов [Красилов 1992].

Несмотря на кажущееся всемогущество информационных технологий, они во многом беспомощны против сил природы. Так, сильные геомагнитные бури могут вызвать сбои компьютерных систем. Да и просчитать параметры сил природы они могут лишь с определенной долей вероятности. Чем больше общество и государство будут зависеть от информационных технологий, тем уязвимее они будут для кибератак, которые могут парализовать управленческую работу государственного аппарата, вывести из строя инженерно-технические сооружения, поддерживающие жизнеобеспечение социума (электрические сети, водопроводные и канализационные системы и т. п.). Например, киберперехват программ работы светофоров с последующим их изменением может вызвать транспортный коллапс в мегаполисе.

Таким образом, на основе всего вышеизложенного можно сделать вывод о том, что цифровые технологии должны быть лишь инструментом, орудием труда, а не средством, создающим фальшивую виртуальную среду, подменяющую реалии бытия. Только тогда можно избежать цифрового рабства, угрозы электронного тоталитаризма. Уязвимость электронных систем к воздействию природных стихий или злоумышленников вызывает необходимость их дублирования традиционными средствами. Электронных денег - металлическими и бумажными; светофоров - регулировщиками и т. п. Только в этом случае можно добиться гармоничного сосуществования традиционного и информационного обществ и обеспечить военную, политическую, социальную, экологическую, экономическую безопасность государства, как внешнюю, так и внутреннюю.

\section{Литература}

Бехман Г. Современное общество: общество риска, информационное общество, общество знаний. М. : Логос, 2010.

Больбот Т. Ю., Юрьева Л. Н. Компьютерная зависимость: формирование, диагностика, коррекция и профилактика: монография. Днепропетровск : Пороги, 2006.

Бурова (Лоскутова) В. А. Интернет-зависимость - патология XXI века // Вопросы ментальной медицины и экологии. 2000. T. VI. № 1. С. 11-13.

Годовые отчеты. Счетная палата Российской Федерации [Электронный ресурс]. URL: www.ach.gov.ru/activities/annual_report/.

Дрепа М. И. Интернет-зависимость как объект научной рефлексии в современной психологии // Знание. Понимание. Умение. 2009. № 2. С. 189-193. 
Кастельс М. Власть коммуникации: учеб. пособие. М. : ГУ ВШЭ, 2016.

Коэн Р. Социальные последствия современного технического прогресса // Новая технократическая волна на Западе / под ред. П. С. Гуревича. М. : Прогресс, 1986. C. $210-225$.

Красилов В. А. Охрана природы: принципы, проблемы, приоритеты. М. : Ин-т охраны природы и заповедного дела, 1992.

Пан А. С.-К. Укрощение цифровой обезьяны: как избавиться от интернетзависимости. М. : АСТ, 2014.

Правительство России. Документы [Электронный ресурс]. URL: http://government. $\mathrm{ru} / \mathrm{docs} /$.

Севостьянова Е. П., Уривская Н. С. К проблеме компьютерной зависимости в подростковом возрасте // Современная психология: материалы IV Междунар. науч. конф. (г. Казань, октябрь 2016 г.). Казань : Бук, 2016. С. 9-11.

Сколимовски Х. Философия техники как философия человека // Новая технократическая волна на западе. М. : Прогресс, 1986. С. 240-250.

Тоффлер Э. Шок будущего. М. : АСТ, 2002.

Эллюль Ж. Другая революция // Новая технократическая волна на Западе / под ред. П. С. Гуревича. М. : Прогресс, 1986. С. 147-153.

Ясперс К. Современная техника // Новая технократическая волна на Западе / под ред. П. С. Гуревича. М. : Прогресс, 1986. С. 119-147.

Suwa M., Suzuki K. The Phenomenon of "Hikikomori" (Social Withdrawal) and the Sociocultural Situation in Japan Today // Journal of Psychopathology. 2013. No. 19. Pp. 191-198.

Teo A. R. Social Isolation Associated with Depression: A Case Report of Hikikomori // International Journal of Social Psychiatry. 2013. № 59. C. 339-341.

UConnect: перехват управления автомобилями через Интернет [Электронный реcypc]. URL: https://www.computerra.ru/180994/uconnect-car-exploit/. 